\title{
Biological Control of Pink Bollworm Pectinophora gossypiella (Saunders) by protease and Lipase Enzymes Produced from Streptomyces vinaceusdrappus SA (AB857336)
}

\author{
W.A. Hassanein ${ }^{1}$, F. M. Reda ${ }^{1 *}$ and E.M. Abdel Azem ${ }^{2}$ \\ ${ }^{1}$ Botany Department, Faculty of science, Zagazig University, \\ Zagazig and ${ }^{2}$ Plant Protection Research Institute, Agriculture \\ Research Center (ARC), Sharkia Branch, Egypt.
}

\begin{abstract}
S TREPTOMYCES vinaceusdrappus SA was subjected to $\checkmark$ submerged fermentation under optimum conditions, at $30^{\circ} \mathrm{C}$ and $\mathrm{pH} 7.0$ in presence of $1 \%$ casein \& $0.5 \%$ maltose and $0.5 \%$ yeast \& $1 \%$ sucrose for 6 and 5 days for protease and lipase production, respectively, under static conditions. Partial purification of protease and lipase were carried out by $70 \%$ ammonium sulphate precipitation, dialysis, Sephadex $\mathrm{G}_{100}$ and finally Sephadex $\mathrm{G}_{50}$. The specific activities of protease and lipase at final purification step were 116.7 and $104.9 \mathrm{U} \mathrm{mg}^{-1}$ protein compared to 8.4 and $8.9 \mathrm{U} \mathrm{mg}^{-1}$ crude proteins, with yield 37 and $29 \%$, respectively. Both enzymes gave single homogenous band of $71 \mathrm{kDa}$ by SDS- PAGE. Also, their optimum $\mathrm{pH}$ was 7.0 and they had $\mathrm{pH}$ stability from $7.0-11.0$. The maximum enzyme activities obtained at $55^{\circ} \mathrm{C}$ and $60^{\circ} \mathrm{C}$ with $\mathrm{Tm}$ (half life temperature) values 86.5 and $83.9^{\circ} \mathrm{C}$ for protease and lipase, respectively. The penetration of newly hatched larvae of pink bollworm into the cotton bolls after being dipped in crude or purified protease and lipase each alone or in mixture (v/v) were studied. The results revealed that the penetration percent decreased in pure enzymes than crude. Treatment with the mixed crude enzymes decreased the percentage of penetration than of each enzyme alone. Also, crude lipase, protease and their mixture had repellent action for pink bollworm moths. Moreover, there was highly significant effect on the deformed adult percentage compared with control since the pure enzyme had effective role than crude enzyme.
\end{abstract}

Keywords: Biocontrol, Pectinophora gossypiella, Larval and Pupal mortality percent, Protease and Lipase enzymes, Kinetic properties.

Pesticides in modern agriculture are under pressure to be removed from the market because of their hazardous impact on the natural environment. So, biological control agents, either by effective microorganisms or microbial products, have long been attracting attention as alternatives to chemical agents (Mahfouz and Abou El-Ela 2011). Well-know bacterial agents which have been used successfully for insect control are Bacillus thuringeinsis, Bacillus sphaerisus and Bacillus subitis (Ghribi et al., 2012).

*Corresponding author, E.mail address: Fifi.reda133@yahoo.com 
Enzymes are gradually replacing the use of harsh chemicals in various industrial processes (Malathu et al., 2008). Proteases which hydrolyze peptide bonds of proteins are also known as peptidyl- peptide hydrolase constitute 60$65 \%$ of the global enzyme (Genkel and Tarib, 2006). Also Proteases are obtained from plants, animal organs and microorganisms (Sevinc and Demirkan, 2011). Proteases produced from Streptomycetes are the most important group of secondary metabolites that are widely exploited (Limkhada et al., 2010). Actinomycetes are Gram-positive, mycelium-forming soil bacteria that include many species considered to be among the most important producers of protease (Balachandran et al., 2012).

Lipases, particularly microbial ones, are mostly extracellular and their production is greatly influenced by the medium composition, they have the ability to hydrolyze ester bonds (Nigam and Pandey, 2009). They hydrolyze substrate not only in an emulsified form but also in a micelle state (Reetz, 2002). Lipase plays a key role in the biological turnover of lipid and functioning of biological membranes and the most lipase-producing microorganisms are Bacillus, Pseudomonas, Staphylococcus and Streptomyces (Treichel et al., 2010).

Insect cuticle is the infection site for microorganisms applied for biological control on insects. Lipases, chitinases, proteases as well as other lysozyme enzymes are commonly produced and secreted by microorganisms to degrade the insect cuticle (Pedrini et al., 2006).

Recently, screening, production and formulation of entomo-pathogenic microorganisms with the potentiality for production of insect cuticle degrading enzymes have been received much attention, due to their low deleterious actions on plants, animals and humanbeings. It appears also that microbial degradation of insect protein and lipid (the main component of the insect cuticle) as well as production of proteases and lipases have captured the world wide attention of biocontrol of insect and become the objective of extensive research (Sahebani and Hadavi, 2008). El-Sayed (2008) studied the biological control of pink bollworm Pectinophra gossypiella using protease enzyme produced from microorganisms, also Lokma (2010) detected the lipases as biocontrol agent against corn leaf aphid Rhopaosiphum maidis.

The aim of this study was to produce, purify and characterize proteases and lipases of S. vinaceusdrappus. Studying the latent effect of several biological aspects and capabilities of the purified enzymes each separately or in mixture to degrade the cuticle of Pectinophra gossypiella insect. Also to enable the use of purified enzymes as biological control of the insects.

\section{Material and Methods}

\section{Tested organism}

Streptomyces vinaceusdrappus SA (AB857336) isolated from soil and mostly active against Pectinophra gossypiella (Reda et al., 2013) was used through this investigation.

Egypt. J. Bot., 54, No. 2 (2014) 
Optimization of culture conditions for protease and lipase production

Streptomyces vinaceusdrappus SA was cultivated for protease production on starch nitrate broth medium with replacing of $\mathrm{NaNO}_{3}$ by $0.2 \%$ gelatin (Ammar et al., 1991). For lipase production the tested organism was subcultured on Doxyeast extract-tributyrin broth medium (Elwan et al., 1977). The production of each enzyme was tested at different incubation periods (3-8 days), different temperatures $\left(25-55^{\circ} \mathrm{C}\right)$, different $\mathrm{pH}$-values $(\mathrm{pH} 4-12)$ under shaking and static conditions and in presence of different carbon and nitrogen sources (Kaur et al., 2001).

\section{Assay of enzyme activity}

Protease enzyme activity $(\mathrm{U} / \mathrm{ml})$ of the cell-free filtrate was determined using the method of Thangam and Rajkumar (2000). This method is a modified method of Anson (1938). While, lipase activity was determined by titrimetric method as described by Nahas (1988) and modified by Yu et al. (2007).

\section{Protein determination}

Protein content was estimated by the method of Lowery et al. (1951) using bovine serum albumin (Sigma chemical Co.) for standard curve.

\section{Protease and lipase purification}

Unless otherwise stated, all procedures of protease and lipase purification were carried out at $4^{\circ} \mathrm{C}$. The culture supernatant was first mixed with ammonium sulphate $70 \%$ concentration, with constant and continually stirring (Phibbs and Bernlohr, 1971). The precipitate was then separated by centrifugation at 6000 rpm for $20 \mathrm{~min}$, and the protein was then re-suspended in small amount of sodium phosphate buffer ( $\mathrm{pH}$ 8.0). As mentioned by Ammar (1975) the resuspended pellets were applied to a Sephadex $\mathrm{G}_{100}$ column then Sephadex $\mathrm{G}_{50}$ column which pre-equilibrated with the same buffer.

\section{SDS-PAGE Analysis}

The molecular weights of protease and lipase enzymes from culture of $S$. vinaceusdrappus SA were carried out using SDS-PAGE according to Laemmeli (1970). PageRuler Unstained Protein Ladder, Fermentas marker was used.

\section{Biochemical properties of S. vinaceusdrappus SA purified protease and lipase}

The optimum temperatures and thermal stability of the tested enzymes were determined after incubation the reaction mixture at different temperatures (30$80^{\circ} \mathrm{C}$ ). The enzymes activities were determined for each temperature as described previously.

The thermal inactivation rate $(\mathrm{Kr})$ can be described by the first-order kinetic model (Whitaker, 1972); $\operatorname{Ln}\left(\mathrm{A}_{t} / \mathrm{A}_{\mathrm{o}}\right) \mathrm{k}_{\mathrm{t}} \mathrm{T}$, where $\mathrm{A}_{\mathrm{o}}$ and $\mathrm{A}_{\mathrm{t}}$ are the specific activity at zero and time. The temperature at which the enzyme loss $50 \%$ of its activity (Tm) was calculated from the linear equation of different preincubation temperature at $60 \mathrm{~min}$. 
The optimum $\mathrm{pH}$ and $\mathrm{pH}$ stability of the tested enzymes was determined after incubation the reaction mixture at different $\mathrm{pH}$ values (4-12).

The biocontrol of Pectinophra gossypiella using S. vinaceusdrappus SA crude and purified protease and lipase

In these experiments the treatments was carried out by crude and purified protease with specific activities 8.4 and $116.7 \mathrm{U} \mathrm{mg}^{-1}$ protein, respectively and the used crude and purified lipase had specific activities 8.9 and $104.9 \mathrm{U} \mathrm{mg}^{-1}$ protein, respectively.

Effect of crude and purified enzymes on penetration of newly hatched larvae of pink bollworm in cotton bolls

This experiment aimed to evaluate successful penetration of newly hatched larvae of pink bollworm into cotton bolls after dipping bolls in crude and pure protease and lipase separately or in mixture (v/v). Cotton bolls age (2-3 week old) were collected from a cotton field in Sharkia Governorate during the first week of July 2013 and brought to the laboratory. Bolls were dipped in protease and lipase for 20 seconds, while control bolls were dipped in water only. Enzyme from treated and untreated bolls were left to dry in air under laboratory condition. One newly hatched larva was placed in clean glass jar with a single cotton boll and covered by fine paper and kept under laboratory condition. Ten replicates were prepared for each enzyme treatment as well as control. After $48 \mathrm{hr}$ from treatment the number of pink bollworm larvae successfully penetrated and lived within green cotton bolls in each treatment and control were counted (Elmedany, 2013).

\section{a- Repellent effect of crude and purified enzymes on pink bollworm moths}

This experiment aimed to evaluate the repellent effect of the enzymes on pink bollworm moths. Cotton bolls (2-3 week-old) were collected from the cotton field in Sharkia Governorate during the first week of July 2013 and brought to the laboratory. Bolls were dipped for 20 seconds in the previous crude or purified protease and lipase separately or in mixture (v/v) and left to air dry under laboratory condition. Controls bolls were dipped in water only. One cotton bolls treated and one untreated were suspending in clean glass jars. As the same manner 5 replicates were repeated. Newly emerged moths of pink bollworm were sexed (male and female) and transferred to glass jars (three pairs /glass jar), the moths were fed on $10 \%$ honey solution. Eggs laid per female were counted on both enzyme treated and untreated bolls of each replicate (glass jar) after four days from the treatment. The percentage of repellency value was calculated according to the following equation of Lwande et al. (1985):

$$
\mathrm{D}=1-(\mathrm{T} / \mathrm{C}) \times 100
$$

where: $\mathrm{T}$ and $\mathrm{C}$ represent the mean number of eggs oviposited per females on treated and untreated bolls, respectively.

$\mathrm{D}=$ The percentage of repellency 
b-Mortality effects of crude and purfied enzymes on the percentages of larval mortality, pupal mortality, adult emergency and deformed adult of pink bollworm

This experiment aimed to study the effects of crude and purified enzymes on some biological aspects of cotton bollworm $P$. gossypiella, mixing the diet ( $4 \mathrm{gm}$ ) with the enzymes of $4 \mathrm{ml}$ for each dish. While, the diet of control mixed with water only. Each treatment was replicated five times. Batches of 20 newly hatched larvae each $(0-6 \mathrm{~h}$ old $)$ were transferred to the treated Petri-dishes after 30 minutes from treatment. Treated Petri -dishes were covered by fine and soft paper below the glass cover to prevent larvae escape. All treatments were incubated in the incubator running at constant conditions $26 \pm 1{ }^{\circ} \mathrm{C}$ and $80 \%$ relative humidity. After $24 \mathrm{hr}$ of exposure and feeding, dead and alive larvae were counted. The mortality percentages were estimated.

To study the latent effect of tested isolates on certain biological aspects of $P$. gossypiella, the survived larvae of each treatments were transferred individually to glass tubes $(2 \times 7.5 \mathrm{~cm})$ containing $4 \mathrm{gm}$ of untreated diet. Afterwards, glass tubes were covered with a piece of absorbent cotton and held under the same conditions as mentioned above. Larvae were examined daily to record the date of larval and pupal mortality. Also date of adult emergence and percentage of deformed adult were recorded El-Sayed (2008).

\section{Statistical analysis}

The obtained results of each mortality and biological parameters were subjected to analysis of variance to clear toxicity and latent effect parameters using Costat computer program Cohort Software. P. O. Box 1149, Berkeley CA 9471 (Costat statistic software, 2005).

\section{Results and Discussion}

Optimization of $S$. vinaceusdrappus $S A$ protease and lipase production

The effect of environmental conditions on the production of proteolytic and lipolytic enzymes could play an important role in the induction or repression of the enzyme by specific compounds (Wang et al., 2008). In the present investigation, the maximum protease production was achieved when $S$. vinaceusdrappus $\mathrm{SA}$ was cultivated in starch nitrate broth medium( $\mathrm{pH} 7)$ with replacing of $\mathrm{NaNO}_{3}$ by $2 \%$ gelatin $(\mathrm{pH} 7)$ at $30^{\circ} \mathrm{C}$ for 6 days in presence of $1 \%$ casein and $0.5 \%$ maltose. While, the maximum lipase production was achieved by incubation of tested organism in Dox-yeast extract-tributyrin broth medium $(\mathrm{pH} 7)$ at $30^{\circ} \mathrm{C}$ for 5 days in presence of $0.5 \%$ yeast and $1 \%$ sucrose, under static conditions for both enzymes (Data not shown). These results were almost similar with Abou Zeid et al. (2007) for protease produced by Streptomyces albidofiavus Dakh-52 and Yu et al. (2007) for lipase produced by Yarrowia lipolytica.

\section{Purification of S. vinaceusdrappus SA protease and lipase}

The protease and lipase enzymes were purified as an extracellular enzymes from the liquid cultures of $S$. vinaceusdrappus SA growing under the optimal 
culture conditions, by $70 \%\left(\mathrm{NH}_{4}\right)_{2} \mathrm{SO}_{4}$. From the purification profile of the tested enzymes, the specific activities of protease and lipase were 116.7 and $104.9 \mathrm{U}$ $\mathrm{mg}^{-1}$ protein compared to 8.4 and $8.9 \mathrm{U} \mathrm{mg}^{-1}$ crude protein, respectively. Also, the purification folds were 13.9 and 11.8 with 37 and $29 \%$ yield after sephadexG50 for purified protease and lipase, respectively (Table 1). Similarly, the highly active alkaline protease from $B$. licheniformis MP1 was achieved after purified by Sephadex-G100 gel filtration (Jellouli et al., 2011). Also protease from Streptomyces sp. A6 was purified to 34.56 fold by Sigh and Chhatpar (2011) using gel permeation chromatography. On the other hand, lipase of $S$. thermocarboxydus ME168 was purified to 9.5 fold with $20 \%$ yield following to precipitation by acetone and gel filtration chromatography using sephadexG-200 (H-kittikun et al., 2012). Similarly, Bose and Keharia (2013) stated that the purity of lipase from $P$. aeruginosa AAU2 increased by 4.96 fold after ammonium sulfate precipitation followed by sephadex G-100 gel filtration chromatography.

TABLE 1. Purification steps of $S$. vinaceusdrappus SA protease and lipase.

\begin{tabular}{|c|c|c|c|c|c|c|}
\hline \multicolumn{2}{|l|}{ Purification step } & $\begin{array}{c}\text { Total Activity } \\
\text { (U) }\end{array}$ & $\begin{array}{c}\text { Total Protein } \\
\text { (mg) }\end{array}$ & $\begin{array}{l}\text { Specific activity } \\
\text { (U/ mg.protein) }\end{array}$ & $\begin{array}{c}\text { Purification } \\
\text { Fold }\end{array}$ & Yield \% \\
\hline Crude enzyme & \multirow{4}{*}{ 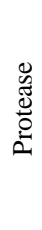 } & 152 & 18 & 8.4 & 1 & 100 \\
\hline Amm. Sulphate $70 \%$ & & 112 & 8.5 & 13.2 & 1.6 & 73 \\
\hline Sephadex $G_{100}$ & & 82 & 1.05 & 78.1 & 9.3 & 54 \\
\hline Sephadex $\mathrm{G}_{50}$ & & 56 & 0.48 & 116.7 & 13.9 & 37 \\
\hline Crude enzyme & \multirow{4}{*}{ 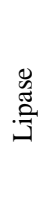 } & 148 & 16.5 & 8.9 & 1 & 100 \\
\hline Amm. Sulphate $70 \%$ & & 102 & 7.6 & 13.4 & 1.5 & 69 \\
\hline Sephadex $\mathrm{G}_{100}$ & & 73 & 0.95 & 76.8 & 8.6 & 49 \\
\hline Sephadex $\mathrm{G}_{50}$ & & 43 & 0.41 & 104.9 & 11.8 & 29 \\
\hline
\end{tabular}

In the present investigation, the homogeneity and molecular mass of each purified protease and lipase enzymes were studied. Each enzyme was appeared as a single protein band of $71 \mathrm{kDa}$ (Fig. 1). This result is unique as only a few reporters are available on the halophilic thermostable protease having such a high molecular weight. Sookkheo et al. (2000) reported that the production of thermostable protease of molecular mass $71 \mathrm{kDa}$ from Bacillus stearothermophilus strain TLS33. Jain et al. (2012) detected the same molecular mass of protease produced from Bacillus sp. SM2014. Abou Zeid et al. (2007) recorded 60 and $35 \mathrm{kDa}$ for alkaline protease of $S$. halstedii Salh-12 and S. endus Salh-40, respectively. While $21 \mathrm{kDa}$ for $S$. thermocarboxydus ME168 lipase was detected by H-kittikun et al. ( 2012). 


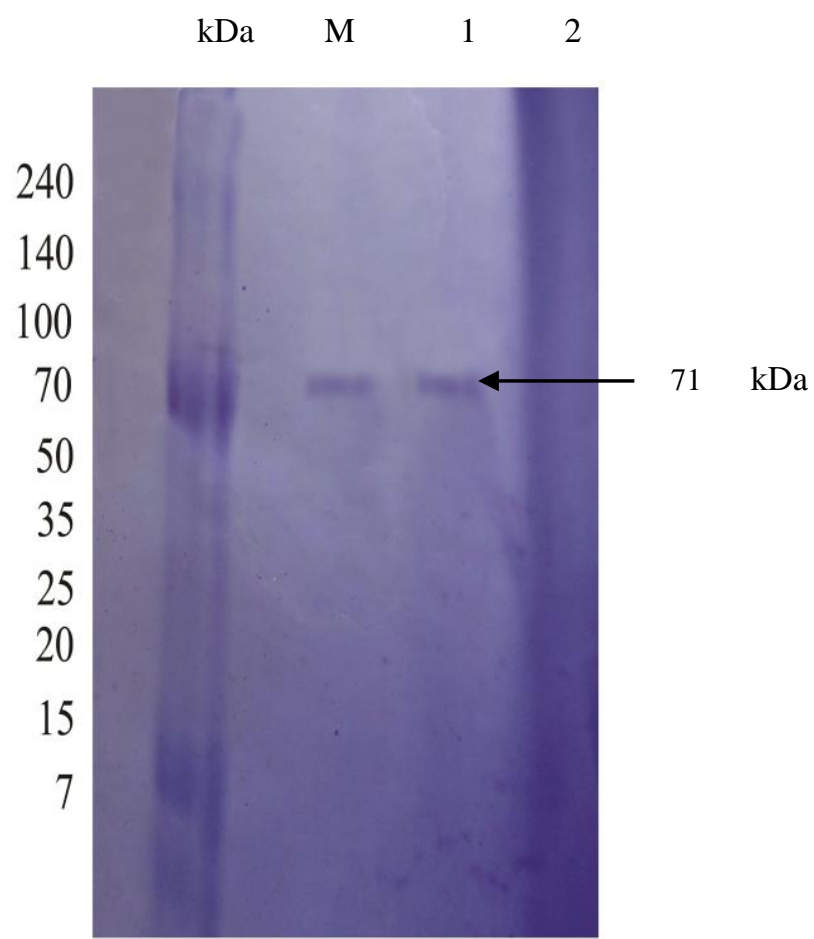

Fig. 1. SDS- PAGE of purified protease and lipase from $S$. vinaceusdrappus. Lane M (Broad-way Daul preslained protein marker), Lane 1, the purified protease enzyme; Lane 2, the purified lipase enzyme.

Biochemical and kinetic properties of $S$. vinaceusdrappus $S$ A protease and lipase

Concerning the biochemical properties of the purified protease and lipase, the maximum protease and lipase activity were at neutral $\mathrm{pH} 7$ and $55 \& 60^{\circ} \mathrm{C}$ respectively (data not shown). These results were agreed with Sigh and Chhatpar (2011). They clarified that the protease of Streptomyces sp. A6 exhibited highest activity at neutral to near-alkaline $\mathrm{pH} 7-9$ and $55^{\circ} \mathrm{C}$. Also, Jain et al. (2012) detected $60^{\circ} \mathrm{C}$ for maximum protease activity produced from Bacillus sp. Li et al. (2009) characterized an alkaline protease from $B$. licheniformis YPIA with optimum activity at $\mathrm{pH} 9.5$ and $60^{\circ} \mathrm{C}$. Also, H-kittikun et al. (2012) detected the maximum activity of lipase from $S$. thermocarboxydus $\mathrm{ME} 168$ at $50^{\circ} \mathrm{C}$. Thermal and $\mathrm{pH}$ stability of the enzyme may be related to that the enzyme maintains its secondary and tertiary structure under stress but lowering of enzyme activity at high temperature or $\mathrm{pH}$ (above the maximum range) may be due to enzyme aggregation, incorrect structure formation, hydrolysis of S-S bonds, deamination and denaturation (Ahern and Klibanov, 1987).

Linear relation between the relative activity and reaction time of both enzymes at different temperatures $\left(30,40,50,60,70\right.$, and $\left.80^{\circ} \mathrm{C}\right)$ were observed 
in (Fig. 2 a, b). It was found that, protease and lipase under investigation were expected to be inactivated above $80^{\circ} \mathrm{C}$. Regarding thermal kinetic parameters, thermal inactivation rate $(\mathrm{kr})$ and half-life time $\left(\mathrm{T}_{1 / 2}\right)$ decreased as temperature increased and the recorded half-life temperature Tm were 86.5 and $83.9^{\circ} \mathrm{C}$ for protease and lipase, respectively (Table 2). Concerning this finding, Sigh and Chhatpar (2011) found that, the protease of Streptomyces sp. A6 was highly stable at temperature prevailing under field conditions $\left(40^{\circ} \mathrm{C}\right)$ as apparent from $\mathrm{kr}$ and $\mathrm{T}_{1 / 2}$ values 0.0065 and $106.75 \mathrm{~min}$, respectively. H-kittikun et al. (2012) found that lipase of $S$. thermocarboxydus ME168 showed high stability at a broad $\mathrm{pH}$ and was thermostable at the temperature range $25-60^{\circ} \mathrm{C}$ with half life of $180 \mathrm{~min}$ at $65^{\circ} \mathrm{C}$.

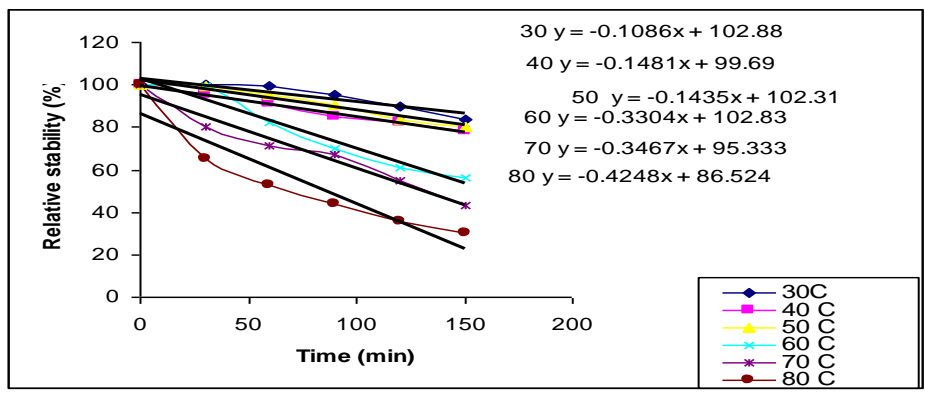

(a)

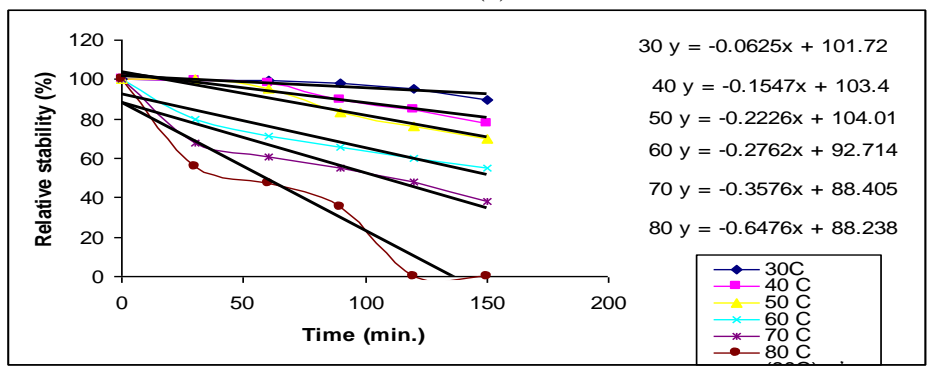

(b)

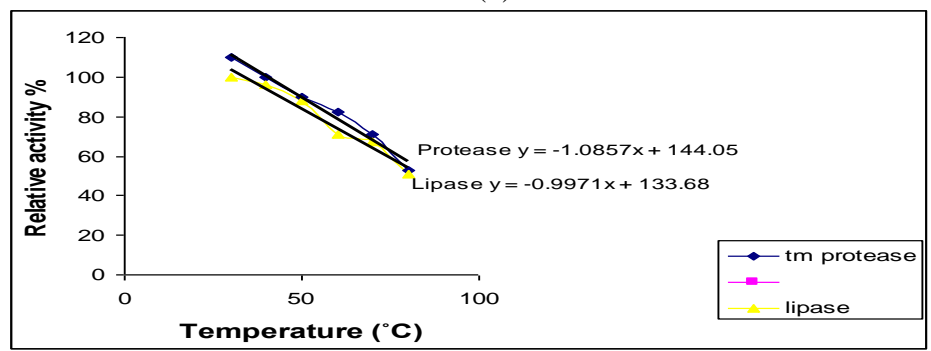

(c)

Fig. 2. Thermal stability profile of $S$. vinaceusdrappus for both enzymes, after incubation of enzymes at different temperature $\left(30-80^{\circ} \mathrm{C}\right)$ and various periods (30-150 min), the residual activity was determined by the standard assay method (a) protease enzyme and (b) lipase; (c) Thermal inactivation profile for protease and lipase, Tm is temperature degree at which the enzyme retains half of its initial activity at $60 \mathrm{~min}$.

Egypt. J. Bot., 54, No. 2 (2014) 
TABLE 2. Thermal inactivation parameters of $S$. vinaceusdrappus SA on the activity of protease and lipase.

\begin{tabular}{|c|c|c|c|c|c|c|}
\hline \multirow[b]{2}{*}{$\begin{array}{c}\text { Temperature } \\
\left({ }^{\circ} \mathbf{C}\right)\end{array}$} & \multicolumn{3}{|c|}{ Protease } & \multicolumn{3}{|c|}{ Lipase } \\
\hline & $\mathbf{T}_{1 / 2}(\mathbf{h r})^{*}$ & $\operatorname{kr} \mathbf{S}^{-1 * *}$ & $\begin{array}{c}\operatorname{Tm}^{* * * *} \\
\left({ }^{\circ} \mathbf{C}\right)\end{array}$ & $\mathbf{T}_{1 / 2}(\mathbf{h r})^{*}$ & $\operatorname{kr} S^{-1 * *}$ & $\begin{array}{c}\mathbf{T m}^{* * * *} \\
\left({ }^{\circ} \mathbf{C}\right)\end{array}$ \\
\hline 30 & 8.11 & $1.09 \times 10^{-3}$ & \multirow{6}{*}{86.5} & 13.8 & $6.28 \times 10^{-4}$ & \multirow{6}{*}{83.9} \\
\hline 40 & 6.10 & $1.56 \times 10^{-3}$ & & 5.8 & $1.57 \times 10^{-3}$ & \\
\hline 50 & 5.59 & $1.47 \times 10^{-3}$ & & 4.1 & $2.28 \times 10^{-3}$ & \\
\hline 60 & 2.67 & $3.57 \times 10^{-3}$ & & 2.6 & $3.29 \times 10^{-3}$ & \\
\hline 70 & 2.17 & $4.09 \times 10^{-3}$ & & 1.8 & $4.64 \times 10^{-3}$ & \\
\hline 80 & 1.44 & $5.83 \times 10^{-3}$ & & 0.98 & $9.69 \times 10^{-3}$ & \\
\hline
\end{tabular}

* Half-life times $\left(\mathrm{T}_{1 / 2}\right)$ expressed by hours.

** Thermal inactivation rate (kr) expressed per seconds.

*** Half-life temperature $(\mathrm{Tm})$ expressed by ${ }^{\circ}$.

Moreover it was found that the purified tested enzymes showed a wide range of $\mathrm{pH}$ stability. Data in (Fig. 3) showed that, the tested enzymes were approximately stable between $\mathrm{pH} 7.0$ to 11.0 and the activities significantly decreased below and above these value. The present findings suggest that, the two enzymes are alkaline in nature. This result is almost similar with Zambare et al. (2011) and Bose and Keharia (2013) for protease produced by P. aeruginosa MCM B-327 and for lipase produced by P. aeruginosa AAU2, respectively.

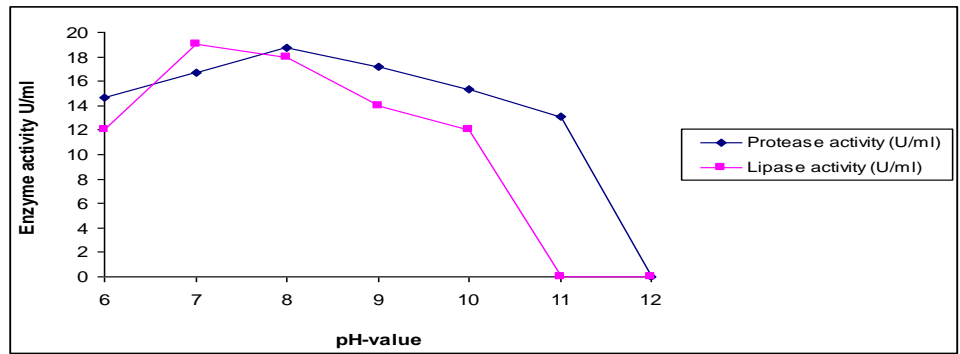

(a)

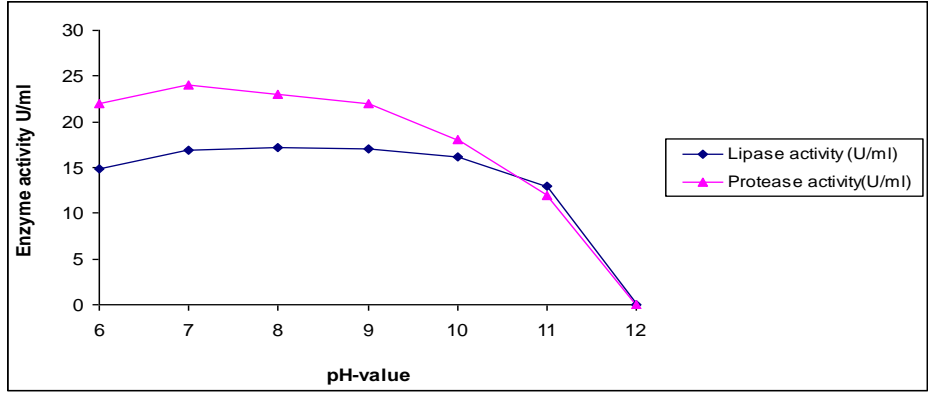

(b)

Fig. 3. The $\mathrm{pH}$ value(a) and $\mathrm{pH}$ stability profile (b) of $S$. vinaceusdrappus protease and lipase. 


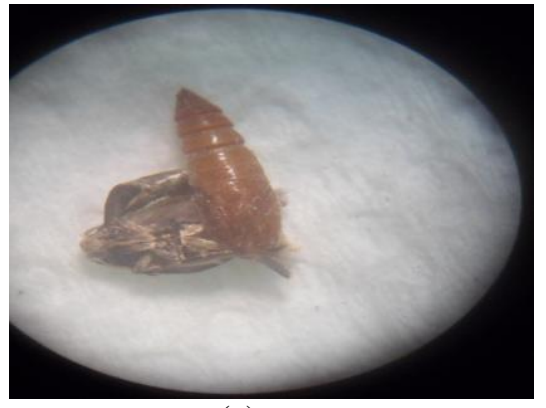

(a)

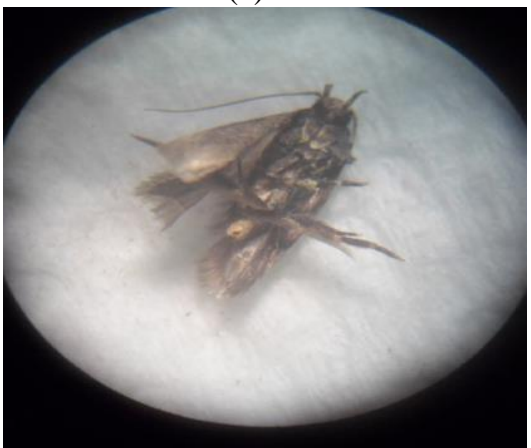

(c)

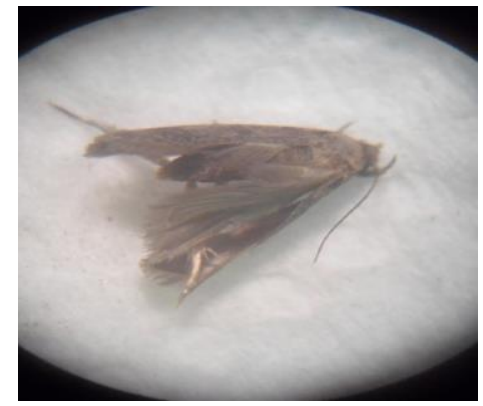

(b)

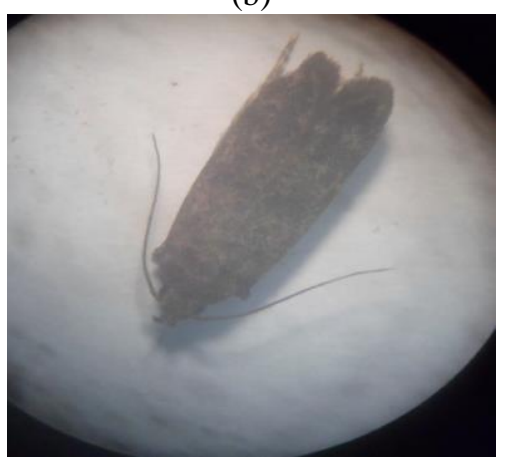

(d)

Fig. 3. Effect of treatment with purified $S$. vinaceusdrappus protease and lipase mixture (v/v) (a) Adult larvae cannot emerge from pupa due to treatment by the mixture of both pure enzymes; (b) Deformed adult of Pectinophra gossypiella treated with the purified mixture (c) Deformed adult of Pectinophra gossypiella treated with mixed purified enzymes, and (d) Control (without treatment).

Biocontrol of Pectinophra gossypiella using crude and purified $S$. vinaceusdrappus SA protease and lipase

a- Effect of $S$. vinaceusdrappus SA crude and purified enzymes on penetration of newly hatched larvae of pink bollworm in cotton bolls

The penetration of newly hatched larvae of pink bollworm into the cotton bolls after being dipped in different enzymes treatment are presented in (Table 3). The mixed purified enzymes treatment only $30 \%$ of the larvae were penetrated into the cotton bolls while penetration increased in presence of each purified enzyme alone. On the other hand, penetration percentage decreased in purified enzymes than crude enzymes. Also, the mixed crude enzymes penetration percentage decreased than the treatment of each crude enzyme alone. The highest successful penetration of newly hatched larvae of pink bollworm $(60.00 \%)$ was recorded with crude protease or lipase as compared with $80.00 \%$ for control. Also, Elmedany (2013) detected the similar results on spiny bollworm when treated with garlic oil. 
TABLE 3. Effect of crude and purified $S$. vinaceusdrappus SA protease and lipase on penetration of newly hatched larvae of Pectinophra gossypiella into cotton bolls.

\begin{tabular}{|c|c|c|c|c|}
\hline \multicolumn{2}{|c|}{ Enzyme treatment } & Alive larvae & Dead larvae & \%Penetration \\
\hline \multirow{3}{*}{ Crude } & protease & $6 \mathrm{~b}$ & $4 \mathrm{~b}$ & $60 \mathrm{~b}$ \\
\cline { 2 - 5 } & lipase & $6 \mathrm{~b}$ & $4 \mathrm{~b}$ & $60 \mathrm{~b}$ \\
\cline { 2 - 5 } & Mixed & $5 \mathrm{bc}$ & $5 \mathrm{ab}$ & $50 \mathrm{bc}$ \\
\hline \multirow{3}{*}{$\begin{array}{c}\text { Purifie } \\
\text { d }\end{array}$} & protease & $4 \mathrm{bc}$ & $6 \mathrm{ab}$ & $40 \mathrm{bc}$ \\
\cline { 2 - 5 } & lipase & $5 \mathrm{bc}$ & $5 \mathrm{ab}$ & $50 \mathrm{bc}$ \\
\cline { 2 - 5 } & Mixed & $3 \mathrm{c}$ & $7 \mathrm{a}$ & $30 \mathrm{c}$ \\
\hline \multicolumn{2}{|c|}{ Control } & $8 \mathrm{a}$ & $2 \mathrm{c}$ & $80 \mathrm{a}$ \\
\hline \multicolumn{2}{|c|}{ F. test } & $\mathrm{n} \mathrm{.s.}$ & $* * *$ & $* * *$ \\
\hline \multicolumn{2}{|c|}{ LSD 0.05} & 1.8947 & 1.6213 & 16.213 \\
\hline
\end{tabular}

b-Repellent effect of S. vinaceusdrappus SA protease and lipase on pink bollworm moths

Data in (Table 4) showed that the tested enzymes had powerful repellent action for pink bollworm moths. It was found that, zero deposited eggs was observed when bolls were treated with the mixed pure protease and lipase as bolls compared with 49 eggs for control, resulting in $100.00 \%$ repellent actions. While using purified protease or lipase alone, the treated bolls recorded 4, 5 deposited eggs as bolls compared with 56 and 55 eggs for control resulting in 92.9 and $90.26 \%$ repellant effect respectively. These results agree with the findings of Ahmed et al. (2007), They observed that the repellent effect of some oils on both pink boll worm moths and egg lying reduced significantly on the treated bolls.

Also data in the same table showed that crude protease, lipase and their mixture had repellent action for pink bollworm moths, where the treated bolls recorded 53, 49 and 51 deposited eggs as boll compared with 21, 19 and 2 eggs for control, resulting in $60.38,61.64$ and $81.05 \%$ repellent actions respectively. These repellent actions may be due to bad odor and viscosity of purified enzyme since the moths can not lay eggs on the bolls. This result is almost in agreement with Wimalaratne et al. (1996). They found that the volatile extracts of pepper tree leaves Schinus molle have repellent activity against the house fly Musca domestica. Also, Hegab (2008) reported the repellent effect of Z-seed oil of Zanzalacht tree Azadirchtaa indica against the bollworms newly hatched larvae. Moreover, this results are similar to Elmedany (2013) using volatile oil on spiny bollworm.

TABLE 4. Repellent effect of crude and purified $S$. vinaceusdrappus SA protease and lipase of pink bollworm moths.

\begin{tabular}{|c|c|c|c|c|}
\hline \multicolumn{2}{|c|}{ Enzyme treatment } & Control & Treated & \%repellent \\
\hline \multirow{3}{*}{ Crude } & Protease & $48.6 \mathrm{c}$ & $19 \mathrm{~b}$ & $61.64 \mathrm{~b}$ \\
\cline { 2 - 5 } & Lipase & $53 \mathrm{ab}$ & $21 \mathrm{a}$ & $60.38 \mathrm{~b}$ \\
\cline { 2 - 5 } & Mixed & $51 \mathrm{bc}$ & $2 \mathrm{e}$ & $81.05 \mathrm{ab}$ \\
\hline \multirow{3}{*}{ Purified } & Protease & $56 \mathrm{a}$ & $4 \mathrm{~d}$ & $92.8 \mathrm{a}$ \\
\cline { 2 - 5 } & Lipase & $55 \mathrm{a}$ & $5 \mathrm{c}$ & $90.26 \mathrm{a}$ \\
\cline { 2 - 5 } & Mixed & $48 \mathrm{c}$ & $0 \mathrm{f}$ & $100 \mathrm{a}$ \\
\hline \multicolumn{2}{|c|}{ F. test } & $* * *$ & $* * *$ & $* *$ \\
\hline \multicolumn{2}{|c|}{ LSD } & 3.1657 & 1.1859 & 20.08 \\
\hline
\end{tabular}


c- Mortality effects of S. vinaceusdrappus SA crude and purified enzymes on percent of larval mortality, pupal mortality, adult emergency and deformed adult of pink bollworm

1- Larval mortality percentage: Analysis of variance of the data given in Table (5) indicated highly significant effects between the enzyme treatments on larval mortality percentages of pink bollworm compared with control. The highest average percentage of larval mortality $(75.0 \%)$ was recorded with the mixture of purified protease lipase $(1: 1 \mathrm{v} / \mathrm{v})$, whereas the lowest one $(44.0 \%)$ was recorded for crude lipase as compared with control (4.66\%).

TABLE 5. Effect of crude and purified $S$. vinaceusdrappus SA protease and lipase on larval, pupal and adult stages of pink bollworm Pectinophra gossypiella

\begin{tabular}{|c|c|c|c|c|c|}
\hline \multicolumn{2}{|c|}{ Enzyme treatment } & $\begin{array}{c}\text { \% of } \\
\text { larval } \\
\text { mortality }\end{array}$ & $\begin{array}{c}\text { \% of } \\
\text { pupal } \\
\text { mortality }\end{array}$ & $\begin{array}{c}\text { \% of adult } \\
\text { emergence }\end{array}$ & $\begin{array}{c}\text { \% of } \\
\text { deformed } \\
\text { adult }\end{array}$ \\
\hline \multirow{3}{*}{ Crude } & Protease & $46.3 \mathrm{~d}$ & $2.6 \mathrm{a}$ & $93.33 \mathrm{ab}$ & $2 \mathrm{c}$ \\
\cline { 2 - 6 } & Lipase & $44 \mathrm{~d}$ & $1 \mathrm{~b}$ & $93.66 \mathrm{ab}$ & $3 \mathrm{bc}$ \\
\cline { 2 - 6 } & Mixed & $70 \mathrm{~b}$ & $3.2 \mathrm{a}$ & $91.3 \mathrm{~b}$ & $4 \mathrm{ab}$ \\
\hline \multirow{2}{*}{ Purified } & Protease & $55.6 \mathrm{c}$ & $4.33 \mathrm{a}$ & $90.3 \mathrm{~b}$ & $4 \mathrm{ab}$ \\
\cline { 2 - 6 } & Lipase & $48 \mathrm{~d}$ & $4 \mathrm{a}$ & $93 \mathrm{ab}$ & $5 \mathrm{a}$ \\
\cline { 2 - 6 } & Mixed & $75 \mathrm{a}$ & $4.3 \mathrm{a}$ & $90.3 \mathrm{~b}$ & $5.6 \mathrm{a}$ \\
\hline \multicolumn{2}{|c|}{ Control } & $4.66 \mathrm{e}$ & 0.3 & $99 \mathrm{a}$ & $0 \mathrm{~d}$ \\
\hline \multicolumn{2}{|c|}{ F- test } & $* * *$ & $* * *$ & $*$ & $* * *$ \\
\hline \multicolumn{2}{|c|}{ LSD 0.05} & 3.705 & 1.5756 & 4.4114 & 1.3778 \\
\hline
\end{tabular}

2- Pupal mortality percentage:Data in (Table 5) showed that highly significant effect in pupal mortality percentages as compared with control. Mean pupal mortality percentages were $0.3 \%$ in control, while $4.33 \%$ in mixture of purified enzymes and purified protease while the lowest effect on pupal mortality was $1.0 \%$ when using crude lipase against pink bollworm.

3- Adult emergence: Data in (Table 5) showed significant effects on adult emergence percentage as compared with control. Adult emergence percentages was $99.00 \%$ with control, but the purified enzyme was effective more than the crude. The most effective treatments were purified protease enzyme and the mixture of purified protease and lipase. These treatments gave $90.3 \%$ of adult emergence.

4- Deformed adult percentage: Data in Table (5) showed highly significant effect on the deformed adult $\%$ compared with control since the purified enzyme had effective role than crude enzyme (Fig. 3). The most effective treatment was the of mixed purified enzymes $(5.6 \%)$ while the lowest value was for crude protease $(2 \%)$. The previous results are almost similar as shown by El Sayed (2008) who revealed a significant effect between the control and the treated Pectinophra gossypiella by protease enzyme produced from Paecilomyces violacea and Paecilomyces varaioti. 
Mahfouz and Abou El-Ela (2011) mentioned that microbes could be used where chemical pesticides are banned. Also, chemical pesticides contaminate ground, water and enter food chains that have an impact on a wide range of organisms. While microorganisms produce several cuticle degrading enzymes used for biological control as protease on Pectinophra gossypiella (El-Sayed, 2008), chitinase on Callosporuchus maculatus (Ghareeb, 2009) and lipase against Rhopaosiphum maidis (Lokma, 2010).

Microorganisms produce a cuticle degrading enzymes particularly proteases and lipases on the surface of host shell during the infection process (Sahebani and Hadavi, 2008). The microorganisms able to germinate on insect cuticle directly, then secrete complex group of enzymes including protease and lipase to dissolve the cuticle barriers and penetrate the insect haemocoel (Gillespie et al., 1998; Pedrini et al., 2006 and El-Sayed, 2008).

\section{Conclusion.}

S. vinaceusdrappus SA (AB857336) had ability to produce protease and lipase. The purified enzymes showed broad $\mathrm{pH}$ stability and high thermal stability. Also, the crude and purified enzymes are being promising candidates for application as biological control agents to control pink bollworm Pectinophra gossypiella.

Acknowledgements: The authors would like to thank Prof. Dr. Mohamed Mohamed Nada professor of pesticide in Plant Protection Research Institute, Agriculture Research Center (ARC), Sharkia Branch. Zagazig for his guidance for pink bollworm experiments.

\section{References}

Abou Zeid, A.A., Eman, Y. T., Nadia, M. A., El-Zawahry, Y.A. and Reda F.M. (2007) Optimization, purification and characterization of protease production by some actinomycets isolated under certain stress condition. Proceeding of second scientific environmental Conference. Faculty of Science, Zagazig University. 153-175.

Ahern, T. J. and Klibanov, A. M. (1987) Microbial genetic engineering and enzyme technology: Why do enzyme irreversibly inactive at high temperature? Biotec, 1:131136. Gustav Fisher, Stuttgart, New York.

Ahmed, B. I., Onu, I., Mudi, L. and Aliyu, M. (2007) Comparative efficacy of some selected plant derived biopesticides for the control of insect pests of cowpea (Vigna unguiculata (L.) Walp.) in Katsina State, Nigeria.; korean society of crop science, suwon, Korea republic, Korean J. Crop Sci., 52 (2), 183-197.

Ammar, M. S. (1975) Studies on thermophilic bacteria. Ph. D. Thesis, Bot. Microbiol. Dept., Fsac. Sci., Al-Azhar Univ. Cairo, Egypt. 
Ammar, M. S., Louboudy, S. and Abdul-Raouf, U. M. (1991) Distribution, total viable bacteria and identification of the most potent proteolytic bacterial strains isolated from Aswan City. Az. J. Microbiol., 11, 224-238.

Anson, M. L. (1938) The estimation of pepsin, papain and cathepsin with hemoglobin. General Physiol., 22, 79-89.

Balachandran, C., Duraipandiyan, V. and Ignacimuthu, S. (2012) Purification and characterization of protease enzyme from actinomycetes and its toxic effect on cancer cell line (A549). Asian Pacific J. of Topical Biomedicin, S392-S400.

Bose, A. and Keharia, H. (2013) Production, characterization and applications of organic solvent tolerant lipase by Pseudomonas aeruginosa AUU2. Biocatalysis and Agricultural Biotechnology.

Costat Statistical Software, (2005) Microcomputer program analysis version, 6. 311. CoHort Software, Monterey, California

Elmedany, W. A. Z. (2013) Chemical and biological studies on the effect of some plant extracts on spiny bollworm, Earias insulana (Boisd.), M. Sc. Thesis, Faculty of science, Zagazig University, Egypt.

El-Sayed, E. M. A. (2008) Studies on insect cuticle-degrading enzymes by some microorganisms and their role in biocontrol on insects, M. Sc. Thesis. Fac.of Sci., Zagazig Univ. Zagazig, Egypt.

Elwan, S. H., El-Naggar, M. R. and Ammar, M. S. (1977) Characteristics of lipase in the growth filtrate dialysate of Bacillus stearothermophilus growth at $55^{\circ} \mathrm{C}$ using a tributyrin-cup Arabia. 8, 105-119.

Genkel, H. and Turib, C. (2006) Alkaline protease production from alkalophilic Bacillus sp. isolated from natural habitats. Enzyme Microbiol. Technol., 39, 703-710.

Ghareeb, E. M. A. (2009) Physiological studies of some chitinolytic fungi and their role in control of seeds insects. M.S. thesis, Fac. of Sci. Zagazig Univ. Zagazig, Egypt.

Ghribi, D., Elleuch, M., Abdelkefi, L. and Ellouze-Chaabouni, S. (2012) Evaluation of laricidal potency of Bacillus subtilis SPB1 biosurfactant against Ephestia kuehniella (Lepidoptera: Pyralidae) larvae and influence of abiotic factor on its insecticidal activity. J. of Stored Products Research, 48, 68-72.

Gillespie, J. P., Bateman, R. and Charnley, K. (1998) Role of cuticle degrading proteinase in the virulence of Metarhizium spp. for the desert locust, Schistocerca gregaria. J. Invertebr. Pathology, 71, 128-137

Hegab, M. E. M. A. (2008) Studies on some elements of integrated control of cotton bollworms. Ph. D. Thesis, Fac., of Agric. Al-Azhar University., 213 pp.

H-kittikun, A., Prasertsan, P., Zimmermann, W., SeesuriyCHAN, P. and Chaiyaso, T. (2012) Sugar ester synthesis by thermostable lipase from Streptomyces thermocarboxydus ME168. Appl. Biochem. Biotechnol., 166(8), 1969-1982.

Egypt. J. Bot., 54, No. 2 (2014) 
Jain, D., Pancha, I., Mishra, S. K., Shivastav, A. and Mishra, S. (2012) Purification and characterization of haloalkaline thermoactive, solvent stable and SDS-induced protease from Bacillus sp.: A potential additive for laundry detergents. Bioresource Technol., 115, 228-236.

Jellouli, K., Ghorbel-Bellaaj, O., BenAyed, H., Manni, L., Agrebi, R. and Nasri, N. (2011) Alkaline-protease from Bacillus licheniformis MP1: Purification, characterization and potential application as a detergent additive and for shrimp deproteinization, process waste, Process, Biochem., doi: 10. 1016/ j. procbio. 2011.02.012.

Kaur, S., Vohra, R.M., Kapoor, M., Khalial, Q. and Hoondal, G.S. (2001) Enhanced production and characterization of a highly thermostable alkaline protease from Bacillus sp. P-2. W. J. Microbiol. Biotech., 17, 125-129.

Laemmli, U. K. (1970) Cleavage of structural proteins during the assembly of the head of bacteriophage $T_{4}$. Nature (London), 227, 680-685.

Li, S., He, B., Bai, Z. and Ouyang, P. (2009) A novel organic solvent-tolerant Bacillus licheniformis YOLA. J. Mol. Catal. B Enzyme, 56, 85-88.

Limkhada, J. R., Mander, P., Cho, S. S. and Yoo, J. C. (2010) A novel fibrinolytic protease from streptomyces sp. CS648. Proc Biochem., 45, 88-93.

Lokma, N. H. E. M. (2010) Studies on some Egyptian fungi and their relationship with piercing sucking pests M. Sc. Thesis. Fac.of Sci., Zagazig Univ. Zagazig, Egypt.

Lowery, O. H., Rosebrough, N. J., Farr, A. L. and Randall, R. J. (1951) Protein measurement with the Folin phenol reagent. J. Biol. Chem., 139, 265-275.

Lwande, W., Hassnali, P. W., N. Joroge, P. W., Bentley, M. D., Dell Monache, F. and Jondico, J. I. (1985) Anew 6 hydroxy pterocarpan with insect antifeedant and antifungal properties from the roots of Tephrosia hildebrandtii. Vatle. Insect Sci. Applic., 6, 537-541.

Mahfouz, S. A. and Abou El-Ela, A. A. (2011) Biological control of pink bollworm Pectinophra gossypiella (Saunders) Microbial. and Biochemical Technology, 3(2), 3032.

Malathu, R., Chowdhury, S., Mishra, M., Das, S., Moharana, P., Mitra, J., Mukhopadhyay, UK., Thakur, A.R. and Chaudhuri, S.R. (2008) Characterization and wash performance analysis of microbial extracellular enzymes from East Calcutta Wetland in India. Amr. J. Appl. Sci., 5,1650-1661.

Nahas, E. (1988) Control of lipase production by Rhizopus oligosporus under various growth conditions. J. Gen. Microbial., 137, 227-233.

Nigam, P. S. N. and Pandey, A. (2009) "Biotechnology for Agro-industrial Residues Utilization". Springer. 
Pedrini, N., Crespo, R. and Juare, P. (2006) Biochemistry of insect epicutical degradation by entomopathogenic fungi. Comparative Biochem. Physiol. Part C: Toxicology and Pharmacology.

Phibbs, P.V. and Bernlohr, R.W. (1971) Purification properties and regulation of glutamic dehydrogenase of Bacillus licheniformis. J. Bacteriol., 106, 375-385.

Reda, F. M., Nada, M. A. and Abdel-Azeem, E. M. (2013) Study the biological activity of spores and supernatants of some actinomycetal and bacterial isolates on certain aspects of Pectinophora gossypiella (Saunders). Egypt. J. Biol. Pest control.

Reetz, M. T. (2002) Lipases as practical biocatalysts. Curr. Opin. Chem. Biol. 6, 145150.

Sahebani, N. and Hadavi, N. (2008) Biological control of the root-knot nematode Meloidogyne javanica by Trichoderma harzianum. Soil Biology and Biochemistry, Article in Press.

Sevinc, N. and Dermirkan, E. (2011) Production of protease by Bacillus sp.N-40 isolated from soil and its enzymatic properties. J. Biol. Environ. Sci. 5 (14), 95-103.

Singh A. K. and Chhatpar, H. S. (2011) Purification, characterization and thermodynamics of antifungal protease from Streptomyces sp. A6. J. Basic Microbial. 51(4), 424-432.

Sookkheo, B., Sinchaikul, S., Phurakul, S. and Chen, S.T. (2000) Purification and characterization of the highly thermostable protease from Bacillus stearothermophilus TLS33. Protein Express. Purif. 20, 142-151.

Thangam, E. B. and Rajkumar, G. S. (2000) Studies on the production of extracellular protease by Alcaligenes faecalis. World J. Microbiol., Biotech., 16, 663-666.

Treichel, H., Oliverira, d., Mazutti, M. A. Luccio, M. D. and Oliveira, J. V. (2010) A review on microbial lipases production. Food Bioprocess Technol., 3, 182-196.

Wang, S. L., Yang, C. H., Liang, T. W. and Yen, Y. H. (2008) Optimization of conditions for protease production by Chryseobacterium taeanense TKU001. Bioresource Technology, 99, 3700-3707.

Whitaker, J. R. (1972) In "Principles of Enzymology for Food Sciences". Enzyme inhibitors pp. 255-282 New York: Marcel Dekker.

Wimalaratne, P. D. C., Slessor, K. N., Borden, J. H., Chong, L. J. and Abate, T. (1996) Isolation and identification of house fly, Musca domestica L., repellents from pepper tree, Schinus molle. J. Chem. Ecol., 22(1), 49-59.

Yu, M., Lange, S., Richter, S., Tan, and Schmid, R. D. (2007) High level expression of extracellular lipase. Lipase from Yarrowia lipolytica in Pichia pustoris and its purification and characterization. Protein Expresssion and Purification, 53 (2), 255263. 
Zambare, V., Nilegaonkar, S. and Kanekar, P. (2011) A novel extracellular protease from Pseudomonas aeruginosa MCM B-327: enzyme production and its partial characterization. New Biotechnology, 28(2), 173-181.

(Received 20/11/2013; accepted 4/12/2013)

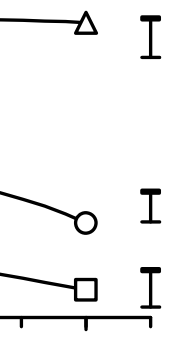

10

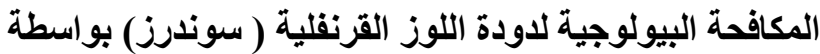 إنزيمى البروتييزو الليباز المنتجين من استربتوفينادينادرابس الترنس}

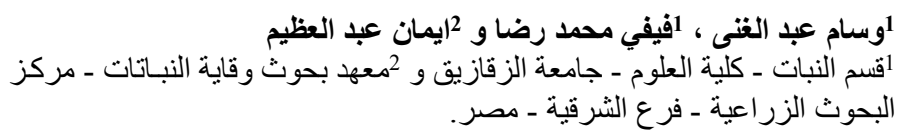

